\title{
Integrating Students in Research under the Supervision of Faculty Members: A Case Study of a University in the United Arab Emirates (UAE)
}

\author{
Ghadah Al-Murshidi \\ Department of Curriculum and Instruction, College of Education, the United Arab Emirates University (UAEU), United Arab Emirates
}

Received October 9, 2019; Revised November 5, 2019; Accepted November 12, 2019

Copyright $\mathrm{O} 2019$ by authors, all rights reserved. Authors agree that this article remains permanently open access under the terms of the Creative Commons Attribution License 4.0 International License

\begin{abstract}
Several scholars have reiterated the significance of undergraduate research and the importance of supervision by faculty members (Lopatto, 2010; Al Morshedi, 2016; Bauer \& Bennett, 2003). This study aims at exposing the prospects and challenges faced by undergraduates during this process of integration from the perspective of the student. Qualitative data was generated using interviews and open ended questionnaires from 24 students and 616 respondents between the ages of 18-45 at a university in the United Arab Emirate. Results reveal that undergraduates suffer challenges, such as unavailability of resources, lack of communication with faculty members and their team when working in a group, time management issues and, inadequate subject knowledge and research orientation amongst others.
\end{abstract}

Keywords Undergraduate Research, Supervision, Faculty Members, United Arab Emirates

\section{Introduction}

Globally, institutions of learning have been continuously transformed to be flexible and adaptive, bridging the gap between abstract theories on education, the learning environment, universal knowledge and the realities of life. The era when teachers in the UAE asked students "closed" questions that did not invite expansive responses is long gone as extended dialogues are now incorporated into lessons so as to create an integrated learning environment. According to (Al Morshedi, 2016), most students lack the desired orientation and guidance to approach research while others are unaware of their cognitive capabilities and problem solving skills which can be honed through participation in research. Student research fosters student learning and this has led to a growing interest in student engagement in research in the university environment (Vereijken et al., 2018). This interest stems from the awareness of the fact that student-supervisor integration is pivotal to the success of a research work and is in fact one of the most rewarding academic partnerships. As stated by Arendale (2014), an integrated approach to learning is one which sees students contributing significantly to the body of knowledge through research, interpretation and communication with their teachers and experienced supervisors. This implies that the student is allowed to explore, investigate, and present findings on topics of research without any limitations but, under the supervision of appropriate authority (Al Morshedi, 2016). This enables these students to exploit their own creativity and ensures that they are trained to be significant contributors to the teaching and learning environment.

The government of the United Arab Emirates has research conscious with setting goals and, has been consistent in its pursuit for research excellence by striving to support institutions that will aid in the achievement of these goals. In the words of the vice president and Prime Minister, Sheikh Mohammed Bin Rashid Al Maktoum, "our goal is to create the means of communication between our young scientists and scientists from around the world, to exchange knowledge, transfer experiences and build our national goal" (Gulf Business, 2017)). This research was inspired by the prevailing push from government and the university regarding the importance of research that is required in different fields whether for the higher education or for the job market. Dekker \& Wolff (2016) postulates that integration between teachers and students provides students with adequate knowledge and the required skills they need to become exceptional professionals in their different fields, significant contributors to their community and successful future leaders to the nation. This is because 
students become self-independent critical thinkers who proffer solutions to problems faced in their immediate environment. This paper intends to explore the effects of collaboration between students and faculty members while carrying out research. In examining the prospects and challenges of this integration, this study will expose its impact on the research student using a university in the United Arab Emirates as a case study.

\section{Understanding Undergraduate-Faculty Integration in Research}

Globally, education is coordinated towards new aptitudes, new perspectives of learning and educating effectively, with new appraisal methodologies. One of these methods falls under the characteristic of researching (Stokking, Schaaf, Jaspers et al., 2004). As stated by Wenzel (1997), "undergraduate research is an inquiry or investigation conducted by an undergraduate that makes an original intellectual or creative contribution to the discipline" (p.163). It is a watchful study that is done to discover and report new learning about a certain aspect of interest. This kind of research is often done using an integrated system. An integrated learning approach is defined as a system that enables the students to explore, gather, refine and present information about the topics one prefers to investigate into the depth without any limitations with the help of an experienced faculty member (Al Morshedi, 2016). It encourages the students to have a strong interconnectedness and interrelationship with their appropriate professors. In this approach, the students have to play the role of an active learner who has to research, interpret, communicate and process learning with others respectively (Arendale, 2014).

Different authors have demonstrated empirically the importance of research in enriching undergraduate experience (Madan \& Teitge, 2013) and, this includes the fact that it enables students to display developments in thinking individualistically, thoughtfully, critically, putting ideas, solving problems, examining data, analysing literature, interpreting study findings, and giving presentations (Buddie, 2011). Programs are designed by the university to foster students' participation in every phase of research and creative activity and this affords students the opportunity to merge theory and practice into a single experience, while allowing students to develop credentials for advanced study and/or employment. Although the nature of each research project has its specifics, it must have well-defined objectives and methods, have a reasonable chance of completion in the available time, and should create new knowledge (Wenzel, 1997). To ensure a fruitful learning experience for the student during this process, student-faculty collaboration has been greatly advised. Student and faculty participants in undergraduate research at institutions of learning frequently report high levels of satisfaction with learning achieved by undergraduates through collaborative research with faculty (Mabrouk \& Peters, 2000; Hakim, 1998; Manduca, 1997).

Prior to the 1980 s, only a few universities had committed significant resources to institution-wide undergraduate research programs that involved the institutions' faculty in regular research collaborations with undergraduates (Al Morshedi, 2016). Currently, this has changed as scholars and universities have touted the benefits of engaging students in research experiences for students as well as faculty. The belief in the value of undergraduate research (UR) for students' education and career development is widely spread and it is only recently that research and evaluation studies have produced results that begin to throw light on the benefits to students, faculty, or institutions that are generated by UR opportunities (Bauer \& Bennett, 2003). Al Morshedi (2016) further states that entering into the worlds of research can be challenging for many students and, studies have shown that these did not really develop an understanding of the complexity of knowledge till their final year "final project /research" or indeed until well after graduation. At institutions where faculties do not place much emphasis on deep learning, the effect of participating in research is actually negative. The focus of most research-based universities is to create an educational environment that benefits undergraduates and simultaneously allows the research oriented faculty, postdoctoral fellows, and graduate students to conduct high-quality research programs with important scientific and social implications. Students are engaged in guided learning by faculty members and in turn contribute to the professional growth of these mentors (Al Morshedi, 2016).

In their study, Portillo et al. (2013) explored the process of students integrating research into their undergraduate classroom experience with focus on how they gathered and analyzed data and integrated their research experience into their overall learning for the course. The findings of their study revealed that the process of research reinforces the learning objectives of the course. Gregerman et al. (1998) postulates that, student-faculty research partnerships are built on the premise that successful retention efforts integrate students into the core academic mission of the university and it targets first-year and sophomore undergraduates. Findings of a participant-control group design show that the research partnerships are most effective in promoting the retention of students. According to Dolan \& Johnson (2010), the faculty-driven approach taken in the Pediatric MPA Laboratory enables faculty to be selective in choosing students who engage in research in the laboratory and ensures that the research activities align with the laboratory's mission. The undergraduate students who participate in research opportunities within the laboratory usually have a keen interest in learning about and gaining additional experience in the areas of pediatric 
movement and obesity-related issues. Hence, undergraduate research has enormous benefits for faculty and students, although these benefits are largely dependent on the faculty member who oversees the experience (Al Morshedi, 2016). Several studies have also revealed that the goal of integrating students in research is to create a link between faculty researchers and undergraduate schooling (Bauer \& Bennett, 2003). As a result of this, resources are expended to provide undergraduates with opportunities to participate in faculty-mentored, hands-on research (e.g., the NSF-sponsored Research Experience for Undergraduates [REU] program, Howard Hughes Medical Institute Science Education Initiatives).

Over the years, institutions in the UAE have taken up the responsibility of growing and promoting a research culture in institutions of learning. One of these is the National Research Foundation of UAE who launched the Young Emirati Researchers Prize in the year 2011, with the aim of promoting young national talents in research work. Initiatives such as this encourage researchers to continue participating in establishing and expanding a solid base of well-informed, competent, and proficient research knowledge workers in the UAE. Undergraduates are further encouraged to think about the high-tech future of the UAE, as it broadens and branches out its resources and tries to realize its dream of a knowledge-based economy. Student research has been documented as an operative high impact practice in higher education (Buddie, 2011). In the $\mathrm{UAE}$, there is a growing awareness of the importance of research and, integrating undergraduate students into research under the supervision of faculty members is a welcome step.

\section{Rationalizing Undergraduate Engagement in Integrated Research Practice}

The Boyer Commission report in 1998 exposed the failure of research institutions in strengthening the quality of undergraduate education through supervised research in the USA. This is a global issue and has drawn international attention to the importance of incorporating research in undergraduate education. Lizzeri and Siniscalchi (2008) opined that engaging students in research projects is often cited as an effective method of creating a link between undergraduate teaching and faculty research. This engagement provides students with the sufficient knowledge and skills needed to succeed in the educational environment and in the real world. Under the supervision of the faculty member, the students have to perform certain tasks assigned to them and gain knowledge from it by carrying them toward the end of the time allocated by the faculty member (Prince et al. 2007). Participation of students in research improves their ability to deal with uncertainty and develop their critical independent thinking skills (self-independent in terms of getting solution confidently for any problem they face in it). It further grooms them to become successful future leaders in different professions and fields they may find themselves. Al Morshedi (2016) posits that there are four main ways of engaging undergraduates with research and inquiry. First is called a research-led study which involves learning about current research in the discipline. Second is research-oriented which involves the development of research skills and techniques, third is research-based and it includes undertaking research and inquiry. Fourth is called a research-tutored study which entails engagement in research discussions.

Thus, faculty members influence the students in research by using their experience to mentor students on the need to create new knowledge. Under appropriate supervision, students develop their thirst for knowledge to a level that they may not just consume existing knowledge, but begin to make discoveries by themselves (Saeed \& Zyngier, 2012). Examining the engagement of undergraduate students and faculty members in research, Kuh, Chen, \& Laird (2007) reveals that the two greatest faculty contributions to undergraduate research are the amount of time dedicated to the experience, and the value that a faculty member places on the experience. Dealing with some of the issues related to the teaching and learning process can be time consuming, but the importance of incorporating these opportunities cannot be understated. Faculty can devise several ways of imbibing the research culture in students by providing students with course credit for research and increasing the amount of research to be done within the specified period of time. Institutions should have a mechanism to award course credit to students for participating in undergraduate research. In some cases, up to 25 percent of a student's normal semester course credit is awarded for research participation. Institutions should define prerequisites and expectations for awarding academic credit for research and scholarly projects. Some programs require all graduating majors to be engaged in research, during the senior year or at some other time. Ideally, these students should have the opportunity to be involved in long-term research projects with the potential to culminate in a significant, written report or artistic demonstration that is drawn from the literature and contributes to the field (Rowlet et al, 2012).

Integrating students into research work under the supervision of faculty members is not beneficial to the students only. On the other hand, it allows the faculty members to test new projects that have been initiated. A recruitment criterion is provided to the mentors by making the use of student's reflection on work experience. These ideas from the students greatly contributes to the success of these research projects as it gives them the opportunity to share their viewpoint with their mentors on the particular topic. Faculty members' development opportunities increase as they provide more guidance to the students they 
are working with (Wrenn, 2009). Undergraduate programs across the US are working to develop students as scholars, integrating independent scholarly experiences into traditional undergraduate classroom environments. For example, George Mason University's Students as Scholars Quality Enhancement Plan; Boston University's Undergraduate Research Opportunities Program; University of Houston's Learning through Discovery; University of Michigan's Undergraduate Research Opportunity Program; etc.). Scholars and universities have touted the benefits of engaging students in research experiences for students as well as faculty.

Likewise, Al Morshedi (2016) states that engagement, motivation, student-centered approaches, and gains in critical thinking skills are all worthy and valid reasons to let them get involved in academic research with faculty members. This partnership can be strengthened through the design of certain structures for educational institutions and private organizations that would enable them to complement each other's needs. At the end, there should be certain strategies developed for the assessment of students working in the research process which would ensure continued improvement and development of the students' abilities. In order to increase the motivation of particular students that were selected for the research work, the mentors have to make them aware that their academic prowess alone is insufficient for a successful career. They have to recognize the potential of the student and work on improving them so as to make them effective contributors in the work while, a supportive style adopted by the faculty members can foster increasing student interest, engagement and the performance in the research.

\section{Methodology}

This study investigates the integration of students in research under the supervision of faculty members from the perspective of undergraduates. This paper was framed as a case study using qualitative data. This study explored perspectives from undergraduates involved in research and thus justified the use of a case study approach as the methodology. As stated by Cohen et al. (2011), a case study digs deep into an issue and explores rigorously the manifold issues or experiences that make up the life of the individual or phenomenon being investigated. The case under study in this paper involves undergraduates of a university in the United Arab Emirates, and all participants were undergraduates from different cultures and backgrounds. Qualitative approach was used to explore the discussion on integration with focus on student's perspectives on how this collaboration influences their performance. The qualitative research approach focuses on phenomena that occur in the natural settings (Cohen et al. 2011), and centers on exploring every piece of information about a subject or phenomenon, bringing to the limelight every detail about the case being explored (Nieuwenhuis (2010). Interviews and questionnaires were used to generate qualitative data with 24 participants chosen purposely from random disciplines under different faculties, and 616 respondents from the questionnaire. These participants were between the ages of $18-45$ and they all consented to be identified on first name basis.

Interviews were appropriate because they provide flexibility in posing questions, in-depth discussions, follow-ups and probes to clarify responses. These interviews and questionnaires were anchored on two basic research questions; firstly, what are the advantages of integrating students in research under the supervision of faculty member? Secondly, what are the challenges of integrating students in research under the supervision of faculty member? The interviews were conducted in English, audio recorded and transcribed while the questionnaire was self-constructed. Among the respondents, $82.6 \%$ were females and $17.4 \%$ were males and responses were gotten from five different faculties. $13.3 \%$ from science, $41.2 \%$ from humanities and social sciences, $10.6 \%$ from business and economics, $13.3 \%$ from education, and $9.6 \%$ from medicine and health sciences. While $57.3 \%$ of respondents were currently taking a research course at the university, $42.7 \%$ were not undertaking any research course at the time of this research. This study is therefore justifiably qualitative and this method ensured the validity and reliability of the results. Data generated were analysed and developed into themes which will be discussed in the findings and discussion section. The major limitation of this study is the inability of the researcher to communicate with sufficient male respondents due to the cultural orientation in the UAE. Some other limitations include the lack of sufficient time and inadequate research resources.

\section{Findings and Discussion}

The data generated from interviews and questionnaires, were coded and categorized into two along the lines of the research questions posed within this paper. Two sets of category emerged; the first deals with the first question and the second with the second question. The first category focused on the advantages of integrating students in research. Under this category, students expressed opinions on the prospects and benefits of integration between students and faculty members. These findings were presented based on emerging themes, and eighteen (18) main themes emerged from the data. These themes include; increasing the students' knowledge, improving students' command of English language, getting more ideas about how research is done, gaining experience, helping in the future career, knowledge of the method of research and its organization, increase in the students' confidence level, contributing to new knowledge, improved technical skills, 
professional advancement, source of inspiration, developing critical analytical skills, enhancing communication skills, getting organized, taking responsibilities and accomplishing them, improving time management skills, widening the network of peer interaction, and personal development.

The second category deals with the challenges of integrating students in research. This category reveals the different opinions expressed by students on the challenges they encounter during the process of integration with faculty members while carrying out research. Twelve (12) main themes emerged from the data obtained in this category. These themes include; unavailability of resources on the research topic, poor writing structure, lack of subject knowledge, inadequate knowledge of citation methods, lack of time management and team playing skills, lack of contact with the faculty members, loss of motivation, difficulty in information management, high level of pressure, non-conformity of gathered information, and loss of concentration.

These themes were further categorised and five overall themes emerged. These themes were; creation of new knowledge, resources, communication and motivation, intellectual advancement and personal development, and fostering vital relationships.

\subsection{Creation of New Knowledge}

Thriving in the world of research can be challenging for many students as a number of institutions in the UAE that do not offer adequate research training to their undergraduates. Studies show that many of the students did not really develop an understanding of the complexity of knowledge till their final year "final project /research" or indeed until well after graduation (Al Morshedi, 2016). Sometimes there is a learning curve based on the student's lack of knowledge that mentors need to address. However, between the orientation session and the student's natural curiosity and desire to learn, this challenge can be resolved. A respondent, Asmaa clearly stated, I became more aware of the world around me through my readings of different articles on our topic of research". Another participant, Mariam opines that "It also helps one to deepen one's knowledge by conducting research and getting ideas and facts from all over the world". For undergraduates, collaborative research widens their links with others for the accomplishment of a number of tasks. Maitha shares this view in her response, "Increasing our knowledge by doing research and getting ideas and facts about the world. We can share our research paper on online and let other people know our thinking and ideas. Research papers are very important for students who are studying in the college and this lets them share their experiences and knowledge". Identification of new and innovative research opportunities is made possible through this integration (Julie, 2012).

Responses from participants also support the view that undergraduate research creates new knowledge and standard that is maintained when it is carried out under the supervision of a faculty member. From 609 responses obtained on the question about gaining knowledge through supervised undergraduate research, $42 \%$ stated that it was very beneficial, while $53.2 \%$ of the respondents agreed it was beneficial. The integration of students and faculty members in research does not only help students gain new knowledge, $94 \%$ of the participants also agree that it was relevant to their course of study. Mughair concurs when he stated that, As a researcher, I sought answers and gained a deeper understanding of what I have learned in the classroom. Similarly, Aysha said, Research helped me to identify the societal and cultural world, and to increase my knowledge and concepts.

There are many students who have benefited from research as it introduces them to new words thereby improving their reading and writing skills. Proficiency in English Language is important in the UAE as Emirati nationals only make up $19 \%$ of the population of the country. Immigrants from South Asia are 50\%, other Arab countries and Iran 23\%, westerners and East Asians 8\%. This led the Abu Dhabi Education Council (ADEC) to implement a bilingual model for curriculum in public schools and launched a school reform program known as the New School Model in 2010 (Index Mundi, 2015). Some participants expressed their opinions on the influence of research activities with their supervisors on their grasp of English language. As Maitha said:

It teaches us how to write in a good way and brings people together to generate improvements. Also, writing a research paper is how you learn to expand your language and increase your vocabulary.

In addition, Aisha Manzar said:

I also felt that my fluency in the English language has become better because usually, the professors tell us to read articles on a particular topic. Muhammad also echoed this when he stated:

Writing research has benefited me in many aspects such as reading and vocabulary. Reading a lot has gained me more new vocabulary to my memory which helps me in writing. My way of writing has improved also by having a wider idea on how to write an article about a certain topic different from another topic in a separate field. Reading a lot has improved my ability to read faster instead of wasting the time on other unimportant things.

\subsection{Intellectual Advancement and Personal Development}

There are several benefits for students who involve themselves in collaborative research. For example, research information exposes undergraduates to better known published works, gives them the opportunity to explore their area of interest, and jump starts their jobs as researchers. Furthermore, through exposure to research as 
students, many undergraduates consolidate on their passion for research and continue on to graduate studies and faculty positions (Madan, \& Teitge, 2013). Some participants expressed personal opinions on this, Mughair stated that

Through research-based learning, I develop the intellectual skills of critical analysis and also valuable transferable skills such as group work, time-management and resource-management and data handling”.

On the other hand, Maria insists that

It has helped me to take in and digest complex ideas, ruminate and reflect over them and discover new ways of approaching and simultaneously developing a solid argument. I can now analyse what is happening and constructively predict things that may not be very obvious in the present.

It further supports students during entering the job market after graduation since it is considered as a positive and solid experience for anyone involved in the research. For instance, helping in writing reports gives them necessary skills in project management, data analysis, organizational skills, writing skills, and communication skills. Aisha said:

In the research, I also learned many research techniques. My problem-solving skills also improved and I learned how to take good decisions in a short amount of time. Undergraduate research helped me to improve my time management skills and work effectively. Planning out your whole research is best, as time is precious.

Jawaher Alkaabi commented:

The research process assists writers in developing better organizational and planning skills while simultaneously increasing insight and knowledge.

In addition, Halima said:

Actually, I improved a lot in terms of writing and organizing my thoughts. The requirement of writing a research paper is helpful in developing my problem-solving skills. I become more capable doing brainstorming and writing outlines for my paper or any project I have to do.

Aysha added:

Writing research papers has a lot of advantages such as teaching us how to communicate ideas and experiments, persuade people of the approach, describe experiments and results, allow others to reproduce your results precisely, and be honest.

All of these skills can be used as very strong platform to these students for marketing themselves to employers in order to obtain the desired job among all of other job seekers. Moreover, these skills can be used later in climbing up the career ladder to reach the highest positions (Gregerman et al., 1998). Results from respondents reveal that $55.5 \%$ of 604 participants attest to the fact that the research integration was beneficial in improving their critical cognitive skills, while $32.7 \%$ said it was very beneficial. $56.7 \%$ of 609 participants also stated that the learning process improved their technical skills. Involving the students in the research projects under the supervision of faculty members is one of the key ways to help them to manage and take ownership of their learning. This is because they begin to set goals and create plans on how these goals will be achieved. It enables them to record their progress as well as their mentor's progress in the work which results in the deepening of their understanding and sense of achievement (Erickson, 2001). Asmaa also revealed that:

There was an increase in my hunger for professional advancement. If I do compelling work, then my research advisor can write a recommendation letter and make a personal referral for me in order to get either a good job in industry or admitted into graduate school. Working directly with a professor will help build a professional network for my field of interest.

In that regard, undergraduate research integration with faculty members develops students personally as it includes activities that improve awareness and identity, develop talents and potential, enhance the quality of life and contribute to the realization of dreams and aspirations (Tamkin et al, 1995). Many students reported a marked improvement in their personal development and virtues such as patience. Aysha agrees and states that:

A Researcher is thought patience during his research because research requires lengthy reading and scientific implementation to arrive at the results.

Halima echoes this in her response when she revealed: Writing a research paper supports my mental wellness as I receive and benefit from more learning resources my mental function in making decisions, willingness to accept various new ideas and setting goals become wider and more flexible.

Participation in academic research helps expose the weakness and strength of the student, enhance the development of self-confidence, the ability to cooperate with others, accept constructive criticism and thinking out of the box. The network of the peer gets broadened as they are supporting one another involved in the research. In addition, it enables students to carefully choose plan their future (professional or academic) that suits and matches their interest (Windham, 2013). Students do not always experience engagement in research in the easy way, over the years their accounts illuminated challenges in several key areas.

\subsection{Resources}

It can be concluded that time like money is an economic resource (Mapolisa \& Mafa, 2011). Most undergraduates are plagued with lack of several resources needed to carry 
out research projects. Some of these challenges include; inadequate time, required data, and lack of cash. Al Morshedi (2016) argues that freshman students should be integrated in carrying out research as well. However, for many freshman students, college courses themselves can be a challenge and expecting them to work on research projects to analyse data and draw conclusion can be very challenging for them. This creates a kind of stress on the students to manage their work of lectures and the research. Asmaa expressed this;

"The main challenge is the time management, as long as the student is trying to choose between his studies at the university and work in research. Moreover, there are many students who are unable to manage time, where the search requires considerable effort".

Most undergraduate students take 15-16 credit hours each semester so the combination of courses, work, and socialization can pose a problem for their engagement in research opportunities. This is more common for students who are participating in the experience on a voluntary basis rather than for course credit. Relative to students' maturity level, younger students are less able to handle the adversity commonly present in research, when there is a need to prioritize and find ways to integrate the various roles and responsibilities related to being a student and a researcher assistant (Robinson, 2013).

Another participant Norah echoed same;

Doing research needs a lot of time and effort. Sometimes, I want a lot of time in searching for a point which is not very important. Also, I may work in groups with my friends who may not finish in time, so I have to wait and stop my work until they finish. That makes me feel bored". In the words of Maria, "The more I put the work offfor the next day, the more daunting it became. And by the time of the deadline, the work looked like an unsalable mountain. As a result, I missed a few deadlines.

Results from the survey reveal that of the 608 responses gotten on the issue of inadequate time available for research, $23.4 \%$ often faced this issue. $31.8 \%$ of 611 participants complained about not finding time for research when working with a team. The faculty members have taught responsibilities as well so they might not have sufficient time to contribute effectively in research projects and train their students (Jones et al, 2010). Ammar's response is a confirmation of this challenge as he recounted his own experience with a faculty supervisor. Ammar states that;

One of the serious challenges during implementation of academic research I faced was the workload of supervisors which considered as a complex element for both sides: supervisor and supervisee. This is due to the fact that faculty members usually carry out other duties such as teaching classes, grading, attending scientific conferences etc.
Institutions also lack resources which hamper the process of teaching and learning through research. Institution related to challenges such as lack of internet facilities, lack of library resources, inability to organize research related workshops also has negative effects. Maitha commented on this issue,

In doing the research I find a lot of resources and some are good while other facts and information are wrong. Also, the availability of good resources is limited and I suffer more in searching for resources rather than writing".

Norah added, some topics have a little information in the library or on Internet.

Maria equally agrees and states that;

If the topic was completely new or abstract, or previously not researched, it became hard to find resources like library books, references, journal articles, etc., that give more information about the topic. Mohammed opines that:

One of those challenges was finding the right articles related to my topic that suited the research. In addition, finding a topic was not enough for the research and the reason why is because that some topics can be attractive but the content is different than what is required. Sometimes having only the name of the article can be misleading for the research so scanning the articles was a must.

\subsection{Communication and Motivation}

Communication between supervisor and supervisee is vital in the research process and both researchers should share information often during the research process. Moreover, the student might lose interest in working on a project that might take a long period of time. This loss of motivation will affect the faculty member who may be expectant of effective results from the student they are working with. Therefore, lack of communication possesses the potential of having negative effects on the student as well as the faculty member (Buddie, 2011). Gamze added,

My supervisor seems to lack commitment and interest in my work as evident by his lack of presence for consultation and lack of inquiry into the progress that I am making.

This lack of communication between integrating participants will eventually affect the quality of work done as the student is left to go through the whole process without proper guidance from an experienced authority. Asmaa further revealed that,

I found some difficulties in dealing with the professor. A lot of students complain that the professor does not give enough information about the subject of research to help students to prepare properly.

Lack of motivation on the part of the undergraduate 
eventually leads to loss of concentration, which is because motivation energizes the student to contribute to the research process. One participant stated that her inability to communicate as often as required with her supervisor made the research process very tiring as it took longer time to complete. Concentration was lost and as little as reading and writing became a herculean task as the topic no longer seemed interesting to her. Without motivation, students lose their sense that energizes them to contribute their work to the research; they feel exhausted. Mughair commented:

I used to lose the sense of motivation to carry on with the research work that I began with due to changing expectations from my side. I felt the long time period of the research made me lose the interest in it.

\section{Maria said:}

One of the first challenges that I experienced was the lack of motivation to conduct research. The reading became more difficult when the topic didn't seem very interesting to me.

Jawaher alkaabi also added:

Staying motivated and following to the plan sometimes, during your research paper, you suffer from various problems causing you to lose interest in the paper.

The biggest challenge can be internal-maintaining the motivation to keep going despite obstacles in your research and the pressures of work and personal commitments", Gamze added.

\subsection{Fostering Relationship with Peers and Faculty Members}

Integrated research implies that two or more people have to work together to accomplish the goal of the research. Most times, these researches are done in groups and relationships are formed amongst team members. To this Asmaa added that:

I was able to make new friends with the students taking part with me in the research through communicating with each other and sharing works with one another.

Mughair commented:

Strengthened my personal/professional mission and vision by exploring opportunities and expanding my horizons in the field of researching, it has provided me an incredible networking opportunity. Not only did I develop some lasting personal and professional relationships but it was also a great way to learn about people from all walks of life

In addition, Aisha insists:

My teamwork skills also improved as I learned how to cooperate with my teammates and figure things out. It was good to have weekly meetings with my teammates and professor where we revised our goals for research and went over the coming week's agenda.

Some researchers have argued that publications may be limited to second tier journals if an undergraduate student is listed as a co-author (Windham, Stevermer, \& Anthes, 2004). As a result, in some organizations, working with student can negatively affect tenure and raise opportunities. Some observers report fear that student research may exploit students in order to promote the faculty member's career. In addition, faculty members observe that research with students may keep them from showing their own research, thereby needing more time or resources, which may not help them with their professional development. A problem also sets in when the undergraduate is not ready properly or if the undergraduate is not motivated enough. (Buddie, 2011).

Communication plays an important role in the research process especially since the research requires team work between the undergraduate and the supervising faculty member (Bouhnik \& Marcus, 2006). Contact among research peers is also a leading factor in determining the success of a research work, which is because information will be freely shared amongst both participants with details on shared responsibilities. Results from the survey reveal that out of 608 participants, $12 \%$ always had difficulty in understanding their role in the research process due to lack of communication and, $31.5 \%$ sometimes did. A participant Maria talked about her experience working with a team on a research project, in her words,

It was a huge challenge was to work with the team and be on the same page as them. It was also difficult to match the timings of all the students and the advisor, so we had to schedule two meetings for the same discussion.

Students vary widely in the formation of a sound peer relationship, but poor contact with peer or faculty member is most times due to the environment of the research. Most students complain about lacking motivation to continue with research because their faculty supervisor is often unavailable. Ammar, a participant in the survey says,

I had a lack of effective communication, either verbal or by email, also other challenges faced by students while proceeding with the academic research. In my opinion working in research under supervision of faculty members doesn't mean that the direction of information's current should be always from the supervisor side.

Some faculty members assume that research with students may keep them from showing their own research, which might slow down their professional development as earlier established. Bearing these in mind, they do not dedicate the required time and resources to carrying out a standard research.

\section{Conclusions}

The purpose of this research stems from the need to explore the prospects and challenges students face within 
the academic environment as it concerns research and supervision by faculty members. This paper sought to understand the in-depth experiences of students in a university in the UAE involved in research with their faculty members so as to illuminate the complex dilemmas, choices, and challenges such as; scientific ways of writing, communication with other research assistants, students and faculty member's relationship, and meeting their expectations of the research task. Based on data gathered and analysed, this paper concludes that students at this university require additional attention from their faculty members who supervise their research projects. Integrating students into research work under the supervision of faculty members ensures that the student enjoys rewarding learning experience. It provides a number of opportunities to the students to share their viewpoints with their mentors on a particular topic of interest and carry on their work about it further with their guidance. However, if it is not properly managed, its adverse effects will overturn its prospects and benefits.

Based on these conclusions, some salient recommendations are made. First, to avoid loss of motivation due to the fact that the research project lingers for a long period of time, faculty members should communicate better with undergraduates under their supervision. Creating time to supervise undergraduates will be easier if faculty members involved in the process are not over occupied with tutoring and administrative duties. Faculty members who are undergraduate mentors should be assigned teaching hours that will give them time to handle these students and also pursue their own research projects. Students should also better manage their time so that they can comfortably handle these research projects alongside their academic work. Ideal students should be selected for these projects and selection should be strictly based on the level of motivation of students in doing the research work. This can be achieved through offering scholarships to students for research-intensive programs.

Summarily, the challenge of inadequate resources can be resolved if institutions fund some of these undergraduate research projects. Undergraduates should avail the opportunity to access grants and monetary awards needed to handle these projects. The university should also ensure that all institution-required resources needed to execute standard research projects are made available.

\section{REFERENCES}

[1] Al Morshedi, G. (2016). Integrating Students in Research Under the Supervision of Faculty Members (Unpublished Dissertation). Department of Curriculum Instruction, College of Education, United Arab Emirates University (UAEU).

[2] Arendale, D.R. (2014). "Understanding the Integrated
Learning Course Model: Academic Transition to Tertiary Education". International Journal of Higher Education, Retrieved from http://www.sciedu.ca/journal/index.php/ijh e/article/view/5324/3450 \

[3] Amy M. Buddie (2011). "Faculty Perceptions of Undergraduate Research". Kennesaw State University, Retrieved fromhttp://blogs.elon.edu/purm/2011/10/11/facu lty-perceptions-of-undergraduate-research-purm-1-1/

[4] Bauer, K. \& Bennett, J. (2003). Alumni Perceptions Used to Assess Undergraduate Research Experience. The Journal of Higher Education, Retrieved from http://sotl.illinoisstate.e $\mathrm{du} /$ downloads/materials/SoTL\%20Perspective.pdf

[5] Bouhnik, D., and Marcus, T. (2006). "Interaction in Distance Learning Courses", Journal of American Society of Science and Technology, Retrieved from http://www.bar oriyan.co $\mathrm{m} /$ portals/0/\%D7\%A $\% \% \mathrm{D} 7 \% 99 \% \mathrm{D} 7 \% 94 \% \mathrm{D} 7 \% 95 \% \mathrm{D} 7 \%$ 9C\%20\%D7\%99\%D7\%93D7\%A2/interaction\%20in\%20d istance $\% 20$ learning\%20courses.pdf

[6] Burke, A. (2011). "Group Work: How to use Groups Effectively". Journal of Effective Teaching, Southern Oregon University, Ashland, Retrieved from http:/uncw.e du/cte/et/articles/Vol11_2/Burke.pdf

[7] Cohen, L., Manion, L., \& Morrison, K. (2011). Research Methods in Education. (7th Ed).

[8] London and New York: Routledge.

[9] Dekker, H., \& Wolff, S.W. (2016). Re-Inventing Research-Based Teaching and Learning. Paper Presented at the European University Association on 5th December, 2016

[10] Dolan, E. L., \& Johnson, D. (2010). The Undergraduate Postgraduate -Faculty Triad. Unique Functions and Tensions Associated with Undergraduate Research Experiences at Research Universities. CBE-Life Sciences Education, 9(4), 543-553

[11] Erickson, R.A. (2001). "Why Involve Students in Research?". National Conference, University of NebraskaLincoln, Retrieved from http://digitalcommons.unl.edu/cgi /viewcontent.cgi?article $=1009 \&$ context $=$ nchcschreyer 2

[12] Gregerman, S., Lerner, J., Hippel, W., Jonides, J., \&Nagda, B. (1998). Undergraduate Student-Faculty Research Partnerships Affect Student Retention. The Review Of Higher Education, 22(1), 55-72. http://dx.doi.org/10.1353/r he. 1998.0016

[13] Gulf Business (2017). Dubai Ruler Launches Scientific Research Center. Retrieved From Https://Gulfbusiness.Co m/Dubai-Ruler-Launches-Scientific-Research-Center/

[14] Hakim, T. (1998). Soft Assessment of Undergraduate Research: Reactions and Student Perspectives. Council on Undergraduate Research Quaterly, 18, 189192

[15] Integrating Undergraduate Research into the Curriculum. (2015). Retrieved from: http://www.cur.org/conferences_a nd_events/institutes/integrating_undergraduate_research_ $\overline{\mathrm{i}}$ nto_the_curriculum/

[16] Index Mundi, (2015). United Arab Emirates Demographic File 2014. Retrieved From http://indexmundi.com/united arab emirates/demographics file.html 
[17] Jones, M.T., Barlow, A.E., \& Villarejo, M. (2010). Importance of Undergraduate Research for Minority Persistence and Achievement in Biology. Journal of Higher Education, 81(1), 82-115

[18] Julie, P. (2012). Faculty Experiences with and Perceptions of Work-Integrated Learning (WIL) in the Ontario Postsecondary Sector. Toronto: Higher Education Quality Council of Ontario, Retrieved from http://www.heqco.ca/S iteCollectionDocuments/WILFacultyENG.pdf

[19] Kuh, G. D., Chen, D., \& Laird, T. F. N. (2007). Why Teacher-Scholars Matter. Liberal Education, 93(4), 40-45. Retrieved from http://search.proquest.com/docview/20982 3820 ?accountid $=62373$

[20] Lizzeri, A., \& Siniscalchi, M. (2008). Parental Guidance and Supervised Learning. The Quarterly Journal of Economics, 123(3), 1161-1195. Retrieved from http://www.jstor.org/st able/25098926

[21] Lopatto, D.E. (2004). Survey of Undergraduate Research Experiences (SURE): First Findings. Cell Biology Education, 3(4), 270-277

[22] Lopatto, D.E. (2010). Why Use Undergraduate Research Experiences? Retrieved May 31, 2016, from http://serc.carl eton.edu/introgeo/studentresearch/Why.html

[23] Mabrouk, P.A., \& Peters, K. (2000). Student Perspectives on Undergraduate Research Experiences in Chemistry and Biology. Retrieved From: http://www.chem.vt.edu/confch $\mathrm{em} / 2000 / \mathrm{a} / \mathrm{mabbrouk} / \mathrm{mabrouk} \cdot \mathrm{htm}$

[24] Madan, R.C., \& Teitge, B.D.(2013). The Benefits of Undergraduate Research: The Student's Perspective. The Mentor: An Academic Advising Journal. Retrieved from http://dus.psu.edu/mentor/.

[25] Manduca, C. (1997). Broadly Defined Goals for Undergraduate Research Projects: A Basis for Program Evaluation. Council on Undergraduate Research Quaterly, $18,64-69$

[26] Mapolisa, T., \&Mafa, O. (2011). Challenges Being Experienced By Undergraduate Students In Conducting Research In Open And Distance Learning.. Retrieved from http://www.aessweb.com/pdf-files/ijass\%20pp.\%201672-1 684.pdf

[27] Nieuwenhuis, J. (2010). Introducing Qualitative Research. In K. Maree (Ed.), First Steps in Research. Johannesburg: Van Shaik.

[28] Portillo, S., Rudes, D., Sloas, L., Hutzell, K., \&Salamoun, P. (2013). Students as Scholars: Integrating Independent Research into Undergraduate Education. Journal of Criminal Justice Education, 24(1), 68-96. http://dx.doi.org/ $10.1080 / 10511253.2012 .655750$

[29] Prince, J.M., Felder, R.M, \& Brent, R. (2007). Does Faculty Research Improve Undergraduate Teaching? An Analysis of Existing and Potential Synergies. Retrieved May 31, 2016, from http://www4.ncsu.edu/unity/lockers/users/f/fel der/public/Papers/Teaching-Research(JEE).pdf

[30] Robinson, L. (2013). Integrating Undergraduate Students in Faculty-driven Motor Behavior Research. Journal Of Physical Education, Recreation \& Dance, 84(9), 28-31. http://dx.doi.org/10.1080/07303084.2013.838112
[31] Rowlett, R. S., Blockus, L., \& Larson, S. (2012) "Characteristics of Excellence in Undergraduate Research (COEUR)". Retrieved from http://www.cur.org/assets/1/23 /COEUR final.pdf

[32] Saeed, S., \& Zyngier,D. (2012). "How Motivation Influences Student Engagement: A Qualitative Case Study". Journal of Education and Learning, Monash University, Melbourne, Retrieved from www.files.assessment-as-learn ing.webnode.com/200000016-6deb66ee45/motivation.pdf

[33] Stokking, K., Van der Schaaf, M., Jaspers, J., \& Erkens, G. (2004). Teachers' Assessment of Students' Research Skills. British Educational Research Journal, 30, 93-116

[34] Tamkin, P., Barber, L., \& Hirsh, L. (1995). "Personal Development Plans: Case Studies of Practice". The Institute for Employment Studies, Retrieved from http://www.empl oyment-studies.co.uk/system/files/resources/files/280.pdf

[35] Vereijken, M.W.C., Van Der Rijst, M.R., Van Driel, J.H., \& Dekker, F.W. (2018). Novice Supervisors' Practices and Dilemmatic Space in Supervision Of Student Research Projects. Teaching In Higher Education, 23(4).

[36] Wenzel, T.J. (1997). What Is Undergraduate Research? Council on Undergraduate Research Quarterly, 17(163).

[37] Windham, T. L., Stevermer, A.J., \& Anthes, R.A. (2004). SOARS(R) - An Overview of the Program and its First 8 Years. Bulletin of the American Meterological Society, 85(1): $42-47$

[38] Windham, S. (2013). Undergraduate Research in German \& European Studies. Retrieved May 31, 2016, from https://burgsburges.wordpress.com/2013/06/28/to-publishor-not-part-1-of- $2 /$ *

[39] Wrenn, J., \& Wrenn, B. (2009). "Enhancing Learning by Integrating Theory and Practice" International Journal of Higher Education, Retrieved from http://www.isetl.org/ijtl he/pdf/IJTLHE727.pdf 